\title{
Iron Oxide-Coated Gravel Fixed Bed Column Study Performance to Remove Mixed Metals from Landfill Leachate
}

\author{
Ibrahim Yildiz ${ }^{1, *}$ and Banu Sizirici ${ }^{2}$ \\ ${ }^{1}$ Khalifa University of Science and Technology, Chemistry Department, Abu Dhabi, P.O Box: 127788, United Arab Emirates \\ ${ }^{2}$ Khalifa University of Science and Technology, Civil Infrastructure and Environmental Engineering Department, Abu Dhabi, P.O Box: \\ 127788, United Arab Emirates
}

\begin{abstract}
Iron oxide-coated gravel as an adsorbent was employed in continuous fixed bed column study to remove $\mathrm{Fe}(\mathrm{II}), \mathrm{Ni}(\mathrm{II})$, and $\mathrm{Zn}(\mathrm{II})$ simultaneously in synthetic leachate samples. Experimental and modeled adsorption capacities derived from the breakthrough curves showed the adsorption capacity order of $\mathrm{Zn}(\mathrm{II})>\mathrm{Fe}(\mathrm{II})>\mathrm{Ni}(\mathrm{II})$. Iron oxide-coated gravel column removed $58.24 \%$ of $\mathrm{Zn}(\mathrm{II}), 47.71 \%$ of $\mathrm{Fe}(\mathrm{II})$, and $39.45 \%$ of $\mathrm{Ni}(\mathrm{II})$. Desorption process was studied in order to test the regeneration capability of iron oxidecoated gravel. It was seen that $99.64 \%$ of $\mathrm{Ni}(\mathrm{II}), 99.54 \%$ of $\mathrm{Fe}$ (II) and $6.75 \%$ of $\mathrm{Zn}$ (II) were recovered through the first cycle of adsorption/desorption. In the second cycle, the recovery rates dropped to $81.4 \%$ for $\mathrm{Ni}(\mathrm{II}), 80 \%$ for $\mathrm{Fe}(\mathrm{II})$ and $4 \%$ for $\mathrm{Zn}(\mathrm{II})$. Based on these results, iron oxide coated gravel has potential to remove mixed metal ions simultaneously in aqueous solutions.
\end{abstract}

\section{Introduction}

High metal concentrations in landfill leachates stem from increasing amounts of electronic wastes, batteries, paints and treated woods in mainstream solid wastes[1, 2]. It was reported that improper management of leachate can pollute environment to a significant extent [3-5]. For that reason, reduction of these metals with effective treatment methods bears critical importance.

Removal of inorganic and organic materials from wastewater samples has been widely carried out through low cost adsorbents such as limestone, zeolite, gravel, sand, peat and industrial waste [6]. Furthermore, external coating of these materials with iron oxide causes changes in the morphology of the surfaces, and this produces novel adsorption sites having high levels of surface defects and reactive surface sites with greater intrinsic reactivity[7-9]. Iron oxide-coated adsorbents removed metals, oxyanionic metals and bacteria [9-20]. Fixed bed studies conducted with iron oxide-coated zeolite showed the removal order of $\mathrm{Pb}(\mathrm{II})>\mathrm{Cu}$ (II) $>\mathrm{Cd}$ (II) $>\mathrm{Cr}$ (II) $>$ $\mathrm{Zn}$ (II) [7]. In addition, a fixed bed column composed of iron oxy hydroxide-coated brick showed the removal order of $\mathrm{Pb}(\mathrm{II})>\mathrm{Cd}(\mathrm{II})>\mathrm{Zn}(\mathrm{II})>\mathrm{Fe}$ (II) $\approx \mathrm{Ni}(\mathrm{II}) \approx$ $\mathrm{Cu}$ (II)[21]. Iron oxide-coated sand in a column showed the adsorption order of $\mathrm{Cr}(\mathrm{VI})>\mathrm{As}(\mathrm{V})$ [22] A column study utilizing zeolite-supported microscale zero-valent iron as adsorbent showed more adsorption for $\mathrm{Pb}$ (II) than $\mathrm{Cd}$ (II) [23]. Another study showed that almost all $\mathrm{Cu}(\mathrm{II})$ and $80 \%$ of $\mathrm{Zn}$ (II) could be removed in a column reactor containing iron oxide-coated gravel [19]. In a similar way, iron oxide-coated sand in a fixed bed column system removed $80 \%$ for $\mathrm{Cu}, 90 \%$ for $\mathrm{Pb}$, and $98 \%$ for
$\mathrm{Cd}[24]$. Morever, iron oxide-coated sand and limestone in a column removed $98.5 \%$ of iron and $95 \%$ of arsenic[25]. Iron oxide-coated peat in up-flow columns simultaneously removed more than $99 \%$ of $\mathrm{Cu}$ and $90 \%$ of $\mathrm{Zn}[26]$. Nano-sized iron oxide-coated sand in a continuous column study removed $90.8 \%$ of turbidity, $73.3 \%$ of $\mathrm{Pb}, 75.8 \%$ of $\mathrm{Zn}, 85.6 \%$ of $\mathrm{Cd}$ and $67.5 \%$ of $\mathrm{PO}_{4}$ in a synthetic urban runoff [27]. A previously reported study showed that iron oxide-coated gravel (IOCG) in a column study showed initial removal of $96.5 \%$ of $\mathrm{Cu}(\mathrm{II}), 94.8 \%$ of $\mathrm{Pb}(\mathrm{II}), 90 \%$ of $\mathrm{Cd}(\mathrm{II}), 84 \%$ of $\mathrm{Fe}(\mathrm{III})$ and $67 \%$ of $\mathrm{Al}(\mathrm{III})$ at $\mathrm{pH} 7$ [28].

A limited number of studies reported the removal efficiency of IOCG in aqueous solutions for individual ions and mixed metals. Since multiple metal ions coexist together in waste water, studies aiming at simultaneous removal of mixed metals will carry more importance towards the implementation of the results in large scale systems. In this study, IOCG as an adsorbent was employed in a fixed bed column study to remove Fe(II), $\mathrm{Ni}(\mathrm{II})$, and $\mathrm{Zn}(\mathrm{II})$ simultaneously from high strength synthetic leachate samples. Adsorption/desorption studies were conducted to evaluate the reusability of IOCG. It is expected that the results of this study will provide a framework in the prediction and evaluation of simultaneous metal ions uptake with IOGC in industrial applications.

\section{Materials and Methods}

\subsection{Filter media preparation}


The gravel used in this study was purchased from Marinara Transport, Abu Dhabi/UAE. It was made up of local rock fragments. The gravel with an average diameter of $2 \mathrm{~mm}-2.38 \mathrm{~mm}$ was chosen in order prevents clogs and high head losses in the filters. Surface coating of the gravel was performed following our one of previous studies [5]. The characterization of gravel and IOCG was performed using scanning electron microscope (SEM), energy-dispersive X-ray (EDX), xRay diffraction (XRD), and Brunauer-Emmett-Teller (BET) surface area analysis, and the details were reported and explained in our previous studies [5, 28, 29].

\subsection{Synthetic leachate preparation}

The synthetic grade leachate was prepared following an established reported protocol[5]. All chemicals were purchased from Fisher Scientific and were of analytical reagent grade. An Atomic Absorption Spectrometer (AAS), Varian FS220, was used to measure the concentrations of the metal ions. The $\mathrm{pH}$ of the leachate samples was measured with a Hach multimeter, HQD4D.

\subsection{Column adsorption studies}

In this study, acrylic flow cell columns having end plate assembles and screens made of two mesh stainless steel were used. The measurements were run in duplicates and the average values were used in the data analysis. The empty columns were cleaned with $3 \%$ of nitric acid solution to remove any residual organic contaminants. Samples of synthetic leachate were mixed with a magnetic stirrer and pumped through the columns upward using a peristaltic pump (Welch Model 3200) to be able to prevent channeling from gravity as shown in Figure 1.

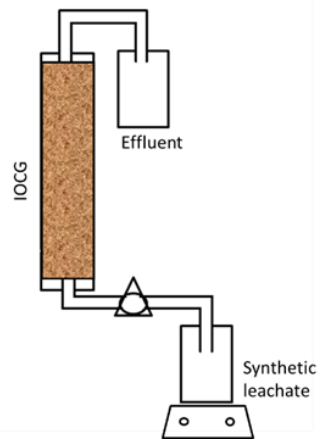

Figure 1. Column set up

The operational parameters with the column specifications are listed in Table 1. Leachate flow was stopped at time $t$ when the concentration of a particular metal ion in the effluent reached to $98 \%$ of its initial concentration according to the formula $\mathrm{C}_{\mathrm{t}}=0.98 \mathrm{xC}_{\mathrm{o}}$ where $C_{t}$ is the metal concentration at time $t$ and $C_{o}$ is the initial metal concentration in the leachate sample. The $\mathrm{pH}$ of the samples were adjusted to 7 for the maximum efficiency of metal removal based on the result of a previous study using IOCG[5]. Effluent samples were collected at different time periods, filtered using $0.45 \mu \mathrm{m}$ syringe filter, and then analyzed with AAS to measure the concentrations of metal ions.

Table 1. Operational parameters and column specifications for column setup

\begin{tabular}{|c|c|}
\hline Operational Parameter & Value \\
\hline Detention time (packed) & $5 \mathrm{~min}$ \\
\hline Total porosity ${ }^{*}$ & 0.25 \\
\hline Feed flow rate & $15 \mathrm{~mL} / \mathrm{min}$ \\
\hline Operating temperature & $23 \pm 1^{\circ} \mathrm{C}$ \\
\hline IOCG weight & $107.06 \mathrm{gr}$ \\
\hline Active bed volume & $76.96 \mathrm{~cm}^{3}$ \\
\hline Total height of column & $35 \mathrm{~cm}$ \\
\hline Active height of column & $15 \mathrm{~cm}$ \\
\hline Inner diameter of the column & $2.54 \mathrm{~cm}$ \\
\hline
\end{tabular}

${ }^{*} \mathrm{p}_{\mathrm{t}}$ : $\left(1-\mathrm{V}_{\mathrm{s}} / \mathrm{V}_{\mathrm{t}}\right), \mathrm{p}_{\mathrm{t}}$ : total porosity, $\mathrm{V}_{\mathrm{s}}$ : soil particle volume, $\mathrm{V}_{\mathrm{t}}$ : Total volume

The total adsorbed metal ion, $\mathrm{q}_{\text {total }}(\mathrm{mg})$, is equal to the area under the plot of the adsorbed ion concentration $\mathrm{C}_{\mathrm{ad}}\left(\mathrm{C}_{\mathrm{ad}}=\mathrm{C}_{0}-\mathrm{C}_{\mathrm{t}}\right)(\mathrm{mg} / \mathrm{L})$ versus time (min) and can be calculated from Eq. (1):

$q_{\text {total }(m g)}=\frac{Q \cdot A}{100}=\frac{Q}{1000} \int_{0}^{t_{\text {total }}} C_{a d} d t$

The dynamic adsorption capacity, $\mathrm{q}_{\mathrm{e}}(\mathrm{mg} / \mathrm{g})$, was calculated from $\mathrm{Eq}(2)$ :

$q_{e}=\frac{q_{\text {total }}}{m}$

The removal efficiency of ions was calculated from the ratio of total adsorbed metal ions in the column to the total amount of metal ions sent to the column based on Eq. (3):

Efficiency $=\frac{q_{\text {total }}}{C_{o_{0}} \frac{Q}{1000} t_{\text {total }}} x 100$

The modeled column adsorption capacities were calculated based on the Thomas model given below,

$\operatorname{Ln}\left(\frac{C_{0}}{C_{t}}-1\right)=k_{T h} q_{0} \frac{m}{Q}-k_{T h} C_{0} t$

The linear plots of $\ln \left[\left(C_{0} / C_{t}\right)-1\right]$ versus $t$ based on the results in column experiments were generated to derive the $k_{\text {th }}$ and $q_{0}$ values which correspond to the slope and intercepts in the graphs.

\subsection{Column desorption studies}

The ability to regenerate IOCG was tested through two cycles of adsorption/desorption process. Exhausted IOCG containing adsorbed metal ions were passed through $0.1 \mathrm{M}$ of $\mathrm{HCl}$ solution with a $15 \mathrm{~mL} / \mathrm{min}$ flow rate. Effluent samples at different time periods were collected in order to determine the desorption ratio[5]. Desorption ratio was calculated based on the following formula: 
Desorption ratio(\%): $\frac{\text { Amount of metal ions desorbed }}{\text { Amount of metal ions adsorbed }} \times 100$

\section{Materials and Methods}

\subsection{Fixed-bed column experiments}

Adsorption of heavy metals by IOCG in a fixed bed column study was presented as $\mathrm{C}_{\mathrm{t}} / \mathrm{C}_{\mathrm{o}}$ per day as shown in Figure 2. For a constant flow rate, 96.5\% removal for $\mathrm{Zn}$ (II) and $77 \%$ removal for $\mathrm{Fe}(\mathrm{II})$ in 5 days and $78 \%$ removal for $\mathrm{Ni}(\mathrm{II})$ in 3 days were observed during the study. Removal rates dropped afterwards. Percent removal became 0 after 21 days of operation for $\mathrm{Fe}(\mathrm{II})$, 15 days for $\mathrm{Ni}(\mathrm{II})$ and 17 days for $\mathrm{Zn}(\mathrm{II})$.

Dynamic adsorption capacity along with exhaustion times and total percent removal for metal ion on IOCG were given in Table 2. A previous study with batch experiments showed that $98.8 \%$ of $\mathrm{Fe}(\mathrm{II}), 88 \%$ of $\mathrm{Ni}$ (II), and $94 \%$ of $\mathrm{Zn}(\mathrm{II})$ can be removed[5]. Furthermore, when compared with a previous batch study, it was found that the removal efficiency of IOCG in fixed-bed columns decreased as a result of decrease in contact time and decrease in contact between adsorbate and adsorbent. This situation resulted in lower retention times for the adsorption process to reach equilibrium which was also argued in another study[30].

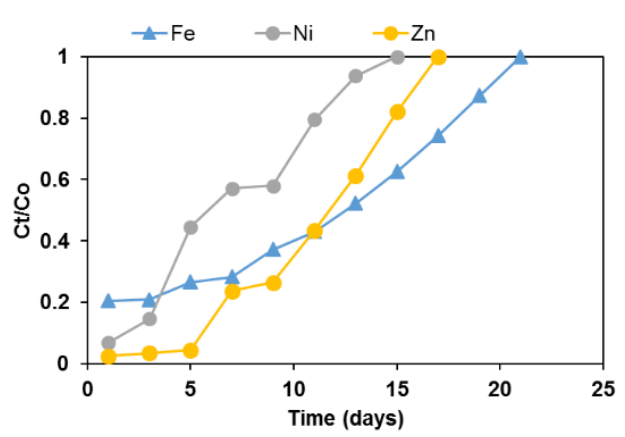

Figure 2. Breakthrough curves corresponding to $\mathrm{Fe}(\mathrm{II}), \mathrm{Ni}(\mathrm{II})$, and $\mathrm{Zn}(\mathrm{II})$ ions in leachate samples

Table 2. Exhaustion times, percent removals and dynamic adsorption capacity

\begin{tabular}{|c|c|c|c|}
\hline Ions & $\mathbf{q}_{\mathbf{e}}(\mathbf{m g} / \mathbf{g})$ & $\mathbf{t}_{\mathbf{e}}$ (days) & \%Removal \\
\hline $\mathbf{N i}(\mathbf{I I})$ & 2.5 & 15 & 39.45 \\
\hline $\mathbf{F e}(\mathbf{I I})$ & 11.29 & 21 & 47.71 \\
\hline $\mathbf{Z n}(\mathbf{I I})$ & 13.24 & 17 & 58.24 \\
\hline
\end{tabular}

The dynamic adsorption capacity order for metals was $\mathrm{Zn}(\mathrm{II})>\mathrm{Fe}(\mathrm{II})>\mathrm{Ni}$ (II) which correlated with the solubility of hydroxides $\left(\mathrm{pK}_{\mathrm{sp}}\right.$ : Ni:15.2, $\mathrm{Zn}: 16.5$, $\left.\mathrm{Fe}^{2+}: 16.31\right)$ as well as the hydrated radius $\left(\mathrm{Zn}: 4.30 \mathrm{~A}^{\mathrm{o}}\right.$, $\left.\mathrm{Ni}: 4.04 \mathrm{~A}^{\mathrm{o}}, \mathrm{Fe}^{+2}: 4.28 \mathrm{~A}^{\circ}\right)[31,32]$. It is apparent that the solubility products $\left(\mathrm{K}_{\mathrm{sp}}\right)$ and the hydrated radius of metals are inherently related to their adsorption capabilities. Ions having smaller hydrated ionic radius are expected to diffuse easier and faster onto the surface of the adsorbent, and as a result they can accumulate in the cracks and channels more as compared to metal ions with larger hydrated radius. Ions with smaller hydrated ionic radius are able to move closer to the adsorbent surface and easily enter the channels in the adsorbent for preferential adsorption[31]. It could be argued that $\mathrm{Zn}(\mathrm{II})$ has a strong affinity towards IOCG on the basis of its higher percent removal rate and its dynamic adsorption capacity. Lower removal efficiency of $\mathrm{Ni}(\mathrm{II})$ could be explained with the concept of charge repulsion. In aqueous solutions with $\mathrm{pH}<8$, nickel ions prefers $\mathrm{Ni}^{2+}$ form, and they compete with $\mathrm{H}^{+}$ions for the negatively charged surfaces on the IOCG. As a result, reduced Ni(II) removal rate could be observed[33]. In parallel, another study reported that $\mathrm{Ni}(\mathrm{II})$ adsorption was considerably lower in the presence of $\mathrm{Cu}$ (II) which competed with $\mathrm{Ni}$ (II) for available adsorption sites. Another reason for the lower Ni (II) removal rate could be lower retention time for Ni(II) to interact with IOCG.

It was noted that the shape of the breakthrough curve is not classical $\mathrm{S}$ shape. Another study reported that mixed metal solutions give different breakthrough curves[5]. Furthermore, different breakthrough curves could be obtained for a particular metal ion when other metal ions are present due to the differences in their adsorption abilities [2, 34].

The breakthrough behavior of metal ions in the leachate samples were analyzed and described in a satisfactory manner using the Thomas model. Using this model, $\mathrm{q}_{0}$ and $\mathrm{k}_{\mathrm{th}}$ corresponding to the three metal ions were calculated. It was shown that IOCG displayed high loading capacity toward these ions in the column studies in which the uptake rate ranged between $15.34 \mathrm{mg} / \mathrm{g}$ to $2.95 \mathrm{mg} / \mathrm{g}$ as shown in Table 3. A previous study showed that IOCG achieved metal ion uptakes of $66.82 \mathrm{mg} / \mathrm{g}$ for $\mathrm{Cu}(\mathrm{II}), 26.5 \mathrm{mg} / \mathrm{g}$ for $\mathrm{Pb}(\mathrm{II}), 23.33 \mathrm{mg} / \mathrm{g}$ for $\mathrm{Cd}(\mathrm{II}), 1.87$ $\mathrm{mg} / \mathrm{g}$ for $\mathrm{Al}(\mathrm{III})$, and $0.56 \mathrm{mg} / \mathrm{g}$ for $\mathrm{Fe}(\mathrm{III})[28]$. Oher studies showed similar results; iron oxide-coated Australian zeolite performed metal ion uptakes of 0.89 $\mathrm{mg} / \mathrm{g}$ for $\mathrm{Cu}(\mathrm{II}), 0.93 \mathrm{mg} / \mathrm{g}$ for $\mathrm{Cd}(\mathrm{II})$, and $0.83 \mathrm{mg} / \mathrm{g} \mathrm{Zn}$ (II); iron-impregnated activated carbon displayed 2.746 $\mathrm{mg} / \mathrm{g}$ for $\mathrm{Cu}(\mathrm{II})$ uptake[7, 8, 14]. The correlation coefficients of Thomas model $\left(\mathrm{R}^{2}\right.$ ranging between 0.95 to 0.97 ) for these ions were very high, and it indicated that this model was a suitable tool to study IOCG adsorption capacities.

Table 3. Constants corresponding to the removal of metal ions in leachate using Thomas model

\begin{tabular}{|c|c|c|c|}
\hline Ions & $\mathbf{q}_{\mathbf{o}}$ (mg/g) & $\mathbf{k}_{\text {th }}$ (L/mg.h) & $\mathbf{R}^{\mathbf{2}}$ \\
\hline $\mathrm{Ni}(\mathrm{II})$ & 2.95 & 0.009805 & 0.95 \\
\hline $\mathrm{Fe}(\mathrm{II})$ & 11.104 & 0.0012 & 0.97 \\
\hline $\mathrm{Zn}(\mathrm{II})$ & 15.34 & 0.0023 & 0.96 \\
\hline
\end{tabular}

A high correlation was observed between experimental and modeled adsorption capacities indicating the applicability of the Thomas model to predict IOCG sorption on metals shown in Table 4.

Table 4. Comparison of experimental and modeled adsorption capacities

\begin{tabular}{|c|c|c|}
\hline Ions & $\mathbf{q}_{\mathbf{o}}$ ( $\left.\mathbf{m g} / \mathbf{g}\right)$ & $\mathbf{q}_{\mathbf{e}}(\mathbf{m g} / \mathbf{g})$ \\
\hline $\mathbf{N i}(I I)$ & 2.95 & 2.5 \\
\hline
\end{tabular}




\begin{tabular}{|l|c|c|}
\hline $\mathbf{F e}($ II) & 11.104 & 11.29 \\
\hline $\mathbf{Z n}($ II) & 15.34 & 13.24 \\
\hline
\end{tabular}

\subsection{Desorption experiments}

The efficiency of metal ion recovery was tested through two cycles of adsorption/desorption process, and in the first cycle the recovery rates of $99.64 \%$ for $\mathrm{Ni}(\mathrm{II}), 99.54 \%$ for $\mathrm{Fe}(\mathrm{II})$ and $6.75 \%$ for $\mathrm{Zn}$ (II) were obtained as shown in Figure 6. In the second cycle, the recovery rates dropped to $81.4 \%$ for $\mathrm{Ni}(\mathrm{II}), 80 \%$ for $\mathrm{Fe}(\mathrm{II})$ and $4 \%$ for $\mathrm{Zn}$ (II). The apparent decline in the recovery of metal ions in the second cycle could be attributed to the dissolution of iron oxide coating upon exposure to $0.1 \mathrm{M}$ $\mathrm{HCl}$ solution for the regeneration process [7, 35]. Nevertheless, the adsorption capacity of regenerated IOCG is still high, and this finding verifies its potential for multiple cycles of metal uptake.

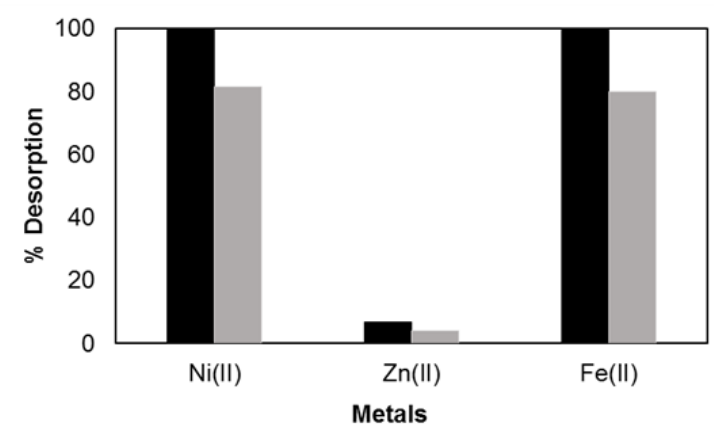

Figure 6. Desorption of metals (black color refers to first cycle and grey color refers to second cycle of adsorption/desorption process

\section{Nomenclature}

$\mathrm{q}_{\mathrm{e}}=$ dynamic adsorption capacity, $\mathrm{mg} / \mathrm{g}$

$$
\mathrm{C}_{0}=\text { initial }
$$
$\mathrm{k}_{\mathrm{Th}}=$ Thomas rate constant (L/mg.h),

concentration of heavy metal $(\mathrm{mg} / \mathrm{L})$

$\mathrm{V}=$ volume of the solution (L)

$\mathrm{m}=$ mass of adsorbent (g). $\mathrm{q}_{\mathrm{e}}=\max$. amount adsorbed, mg/g IOCG $\mathrm{q}_{0}=$ Thomas modeled column adsorption capacity $(\mathrm{mg} / \mathrm{g})$, $\mathrm{C}_{\mathrm{t}}=$ outlet concentration at time $t$ $(\mathrm{mg} / \mathrm{L})$, $\mathrm{Q}=$ flowrate $(\mathrm{mL} / \mathrm{min})$ and

\section{Conclusion}

In this study IOCG was incorporated into column experiments in order to test its efficiency to remove multiple metal ions simultaneously in high strength leachate samples. $\mathrm{Zn}(\mathrm{II})$ ion showed the strongest affinity toward IOCG based on its high breakthrough time. Charge repulsion could be invoked to elaborate the lower removal rate of $\mathrm{Ni}(\mathrm{II})$. Loading capacities of metal ions under dynamic conditions were derived using breakthrough data, and the results showed that IOCG could effectively remove these ions. The experimental and modeled adsorption capacity order was $\mathrm{Zn}(\mathrm{II})>$ $\mathrm{Fe}(\mathrm{II})>\mathrm{Ni}(\mathrm{II})$ with the average removal rate of $58.24 \%$ for $\mathrm{Zn}(\mathrm{II}), 47.71 \%$ for $\mathrm{Fe}(\mathrm{II})$, and $39.45 \%$ for Ni(II). The two cycles of adsorption/desorption study demonstrated that IOCG could be regenerated and reused in metal uptake studies albeit with an apparent decline in the adsorption capacity in the second cycle due to the dissolution of its iron oxide coating. Notwithstanding this observation, it seems obvious that IOCG is a potential material in the removal of metal ions simultaneously from landfill leachate. It could be incorporated into various column designs in fixed bed reactors, and it could be adapted to pilot or large-scale systems in industrial applications. In summary, our work could provide and inspire an initial framework for further studies.

\section{References}

1. Mojiri, A., et al., Metals removal from municipal landfill leachate and wastewater using adsorbents combined with biological method. Desalination and Water Treatment, 2016. 57(6): p. 2819-2833.

2. Daso, A.P., et al., Polybrominated diphenyl ethers (PBDEs) and 2,2 ',4,4 ',5,5 '-hexabromobiphenyl (BB-153) in landfill leachate in Cape Town, South Africa. Environmental Monitoring and Assessment, (2013). 185(1): p. 431-439.

3. Sizirici, B. and B. Tansel, Parametric fate and transport profiling for selective groundwater monitoring at closed landfills: A case study. Waste Management, (2015). 38: p. 263-270.

4. Lins, C., et al., Removal of ammonia nitrogen from leachate of Muribeca municipal solid waste landfill, Pernambuco, Brazil, using natural zeolite as part of a biochemical system. Journal of Environmental Science and Health Part a-Toxic/Hazardous Substances \& Environmental Engineering, (2015). 50(9): p. 980-988.

5. Sizirici, B. and I. Yildiz, Adsorption capacity of iron oxide-coated gravel for landfill leachate: simultaneous study. International Journal of Environmental Science and Technology, (2017). 14(5): p. 1027-1036.

6. Ali, I., New generation adsorbents for water treatment. Chemical reviews, (2012). 112(10): p. 5073-5091.

7. Thuy Chung, N., et al., Simultaneous adsorption of $\mathrm{Cd}, \mathrm{Cr}, \mathrm{Cu}, \mathrm{Pb}$, and $\mathrm{Zn}$ by an iron-coated Australian zeolite in batch and fixed-bed column studies. Chemical Engineering Journal, (2015). 270: p. 393404.

8. Tiwari, D., Lalhmunsiama, and S.-M. Lee, Ironimpregnated activated carbons precursor to rice hulls and areca nut waste in the remediation of $\mathrm{Cu}(\mathrm{II})$ and $\mathrm{Pb}(\mathrm{II})$ contaminated waters: a physicochemical studies. Desalination and Water Treatment, (2015). 53(6): p. 1591-1605.

9. Kan, C.-C., et al., Adsorption of $\mathrm{Mn} 2+$ from aqueous solution using $\mathrm{Fe}$ and $\mathrm{Mn}$ oxide-coated 
sand. Journal of Environmental Sciences-China, (2013). 25(7): p. 1483-1491.

10. Kundu, S. and A.K. Gupta, Adsorption characteristics of As(III) from aqueous solution on iron oxide coated cement (IOCC). Journal of Hazardous Materials, (2007). 142(1-2): p. 97-104.

11. Nguyen, T.V., et al., Arsenic removal by iron oxide coated sponge: Experimental performance and mathematical models. Journal of Hazardous Materials, (2010). 182(1-3): p. 723-729.

12. Buamah, R., B. Petrusevski, and J.C. Schippers, Adsorptive removal of manganese(II) from the aqueous phase using iron oxide coated sand. Journal of Water Supply Research and Technology-Aqua, (2008). 57(1): p. 1-11.

13. Park, S.J., et al., Bimetallic oxide-coated sand filter for simultaneous removal of bacteria, $\mathrm{Fe}(\mathrm{II})$, and Mn(II) in small- and pilot-scale column experiments. Desalination and Water Treatment, (2015). 54(12): p. 3380-3391.

14. Lee, S.-M., C. Laldawngliana, and D. Tiwari, Iron oxide nano-particles-immobilized-sand material in the treatment of $\mathrm{Cu}(\mathrm{II}), \mathrm{Cd}(\mathrm{II})$ and $\mathrm{Pb}(\mathrm{II})$ contaminated waste waters. Chemical Engineering Journal, (2012). 195: p. 103-111.

15. Unob, F., et al., Reuse of waste silica as adsorbent for metal removal by iron oxide modification. Journal of Hazardous Materials, (2007). 142(1-2): p. 455-462.

16. Sud, D., G. Mahajan, and M.P. Kaur, Agricultural waste material as potential adsorbent for sequestering heavy metal ions from aqueous solutions - A review. Bioresource Technology, (2008). 99(14): p. 6017-6027.

17. Zamil, S.S., et al., Correlating metal ionic characteristics with biosorption capacity of Staphylococcus saprophyticus BMSZ711 using QICAR model. Bioresource Technology, (2009). 100(6): p. 1895-1902.

18. Tiwari, D., et al., Manganese-modified natural sand in the remediation of aquatic environment contaminated with heavy metal toxic ions. Chemical Engineering Journal, 2011. 171(3): p. 958-966.

19. Norris, M.J., et al., Treatment of heavy metals by iron oxide coated and natural gravel media in Sustainable urban Drainage Systems. Water Science and Technology, (2013). 68(3): p. 674-680.

20. Kumar, A., et al., Iron oxide - coated fibrous sorbents for arsenic removal. Journal - American Water Works Association, (2008). 100(4): p. 151A4.

21. Allandin, O., et al., Adsorption capacity of iron oxyhydroxide-coated brick for cationic metals and nature of ion-surface interactions. Applied Clay Science, (2014). 90: p. 141-149.

22. Mak, M.S., I.M. Lo, and T. Liu, Synergistic effect of coupling zero-valent iron with iron oxide-coated sand in columns for chromate and arsenate removal from groundwater: influences of humic acid and the reactive media configuration. Water Research, (2011). 45(19): p. 6575-6584.

23. Kong, X., et al., Evaluation of zeolite-supported microscale zero-valent iron as a potential adsorbent for $\mathrm{Cd} 2+$ and $\mathrm{Pb} 2+$ removal in permeable reactive barriers. Environmental Science and Pollution Research, (2017). 24(15): p. 13837-13844.

24. Benjamin, M.M., et al., Sorption and filtration of metals using iron-oxide-coated sand. Water Research, (1996). 30(11): p. 2609-2620.

25. Devi, R.R., et al., Removal of iron and arsenic (III) from drinking water using iron oxide-coated sand and limestone. Applied Water Science, (2014). 4(2): p. 175-182.

26. Kasiuliene, A., et al., Treatment of metal (loid) contaminated solutions using iron-peat as sorbent: is landfilling a suitable management option for the spent sorbent? Environmental Science and Pollution Research, (2019).

27. Khiadani, M., M. Zarrabi, and M. Foroughi, Urban runoff treatment using nano-sized iron oxide coated sand with and without magnetic field applying. Journal of Environmental Health Science and Engineering, (2013). 11(1): p. 43.

28. Sizirici, B. and I. Yildiz, Simultaneous adsorption of divalent and trivalent metal cations by iron oxidecoated gravel. International Journal of Environmental Science and Technology, (2018): p. $1-10$.

29. Sizirici, B., et al., Adsorptive removal capacity of gravel for metal cations in the absence/presence of competitive adsorption. Environmental Science and Pollution Research, (2018). 25(8): p. 7530-7540.

30. Li, C. and P. Champagne, Fixed-bed column study for the removal of cadmium (II) and nickel (II) ions from aqueous solutions using peat and mollusk shells. Journal of Hazardous Materials, (2009). 171(1-3): p. 872-878.

31. Sounthararajah, D.P., et al., Adsorptive removal of heavy metals from water using sodium titanate nanofibres loaded onto GAC in fixed-bed columns. Journal of Hazardous Materials, (2015). 287: p. 306316.

32. Barnum, D.W., Hydrolysis of cations. Formation constants and standard free energies of formation of hydroxy complexes. Inorganic Chemistry, (1983). 22(16): p. 2297-2305.

33. Mahmoud, M.R. and N.K. Lazaridis, Simultaneous Removal of Nickel(II) and Chromium(VI) from Aqueous Solutions and Simulated Wastewaters by Foam Separation. Separation Science and Technology, (2015). 50(9): p. 1421-1432.

34. Zulfadhly, Z., M.D. Mashitah, and S. Bhatia, Heavy metals removal in fixed-bed column by the macro fungus Pycnoporus sanguineus. Environmental Pollution, (2001). 112(3): p. 463-470. 
35. Han, R., et al., Characterization and properties of iron oxide-coated zeolite as adsorbent for removal of copper(II) from solution in fixed bed column. Chemical Engineering Journal, (2009). 149(1-3): p. 123-131. 